\title{
Trends and Directions in Digital Economy Infrastructure Formation: Regional Aspect
}

\author{
Yu. I. Seliverstov \\ Department of economics and organization of production \\ Belgorod State Technological University named after V.G. Shukhov \\ Belgorod, Russia \\ urisel@mail.ru
}

\begin{abstract}
Digital transformation significantly changes entire sectors of the economy and spheres of society. Taking into account that the development of the digital economy in Russia is possible only on the basis of modern information and communication infrastructure, the article discusses its current state and development directions within the framework of the National Project Digital Economy of the Russian Federation. An analysis of the current level of the digital economy infrastructure development in the regions of the Central Black Soil macroeconomic region revealed trends in the expansion of the use of global information systems. Promising areas for further development of the information infrastructure of the region are noted.
\end{abstract}

Keywords: digital economy, information and communication infrastructure, Central Black Soil macroeconomic region

\section{INTRODUCTION}

In the last five to ten years, the world has experienced a real technological and telecommunication revolution. Millions of people around the world, including in Russia, can no longer imagine their existence without daily and even hourly use of mobile devices, mobile Internet, they do not notice that they are surrounded by a huge number of different automatic sensors that collect and transmit information. Thus, we can state that humanity has entered the era of the digital economy.

There exist many different interpretations of the term digital economy. From our point of view, the digital economy can be represented as an economic structure in which data is an independent economic entity. That is, the digital economy is about how we create, transmit, collect, store data, and protect it. But the most important thing is that we analyze the data and make decisions based on them that make our economy more efficient, management more efficient, and therefore improve the quality of life. Digital transformation is changing entire sectors of the economy and different spheres of society. The work of both Russian [1-3] and foreign researchers [4-6] is devoted to the analysis and consideration of these processes. The main engine of digital transformation is new products, services, information technologies, platforms, and improved business models [7,8].

It should be noted that Russia is already living in a digital economy. Thus, during five years (2011-2015), the total volume of the Russian digital economy has increased by $59 \%$, that is, it grew nine times faster than the country's GDP. By the number of Internet users, the Russian Federation ranks first in Europe and sixth in the world [9]. In particular, smartphone users are more than $60 \%$ of the population, and the number of users of state and municipal services portals in

TABLE I. CONTRIBUTION OF RUSSIAN DIGITAL ECONOMY COMPONENTS TO GDP IN COMPARISON WITH OTHER COUNTRIES (IN\% OF GDP)

\begin{tabular}{|c|c|c|c|c|c|c|c|}
\hline Indicator & Russia & USA & PRC & Western Europe $^{* *}$ & Eastern Europe $^{* * *}$ & Brazil & India \\
\hline Households spending in digital sphere & 2.6 & 5.3 & 4.8 & 3.7 & 3.2 & 2.7 & 2.2 \\
\hline Companies' spending on digitalization & 2.2 & 5.0 & 1.8 & 3.9 & 2.7 & 3.6 & 2.0 \\
\hline Government spending on digitalization & 0.5 & 1.3 & 0.4 & 1.0 & 0.6 & 0.8 & 0.5 \\
\hline ICT import & -1.8 & -2.1 & -2.7 & -2.9 & -6.1 & -1.0 & -2.1 \\
\hline Digital economy size & 3.9 & 10.9 & 10.0 & 8.2 & 6.3 & 6.2 & 5.5 \\
\hline
\end{tabular}


V.G. Shukhov Belgorod State Technological University. The theoretical and methodological basis of the study was the fundamental principles of the evolutionary theory of economic change. In the process of developing the research problem, universal methods of scientific knowledge, special methods of complex economic analysis, and tabular visualization of empirical data were used.

The information and empirical base of the study was formed on the basis of data from the Federal State Statistics Service (Rosstat), official websites of regional governments of the Belgorod, Voronezh, Kursk, Lipetsk and Tambov Regions, as well as information materials on the state and development of digital infrastructure published in periodicals and specialized literature.

\section{RESULTS}

We can agree with the point of view of scientists from the Research Institute of Radio (FSUE NIIR), who believe that currently the main promising areas for the development of information communications have become Internet-oriented and mobile world communications. These two vectors have formed a paradigm focused on connecting the objects of the world around us based on the digital technology infrastructure [12].

T.N. Yudina and E.A. Kupchishina believe that the

Research was conducted in the second half of 2019 at the Chair of Economics and Organization of Production of the

TABLE II. KEY INDICATORS OF THE DIGITAL ECONOMY DEVELOPMENT IN THE OF THE RUSSIAN FEDERATION

\begin{tabular}{|c|c|c|c|c|c|}
\hline $\begin{array}{l}\text { Indicator } \\
\end{array}$ & 2013 & 2014 & 2015 & 2016 & 2017 \\
\hline $\begin{array}{c}\text { Internal costs of research and development in the } \\
\text { priority area "Information and Telecommunication } \\
\text { System", in\% of the total internal cost of research } \\
\text { and development }\end{array}$ & 8.0 & 8.3 & 8.2 & 8.3 & $\ldots$ \\
\hline $\begin{array}{l}\text { Publications of Russian authors in the field of ICT in } \\
\text { publications indexed in the Web of Science database: } \\
\text { - total, ea } \\
\text { - in\% of the total number of publications in the field } \\
\text { of ICT }\end{array}$ & $\begin{array}{c}1,529 \\
0,82\end{array}$ & $\begin{array}{c}2,593 \\
1,27\end{array}$ & $\begin{array}{c}3,678 \\
1,62\end{array}$ & $\begin{array}{c}3,927 \\
1,70\end{array}$ & $\begin{array}{l}4,036 \\
2,10\end{array}$ \\
\hline $\begin{array}{l}\text { Patent applications for inventions in the field of ICT, } \\
\text { according to Russian applicants: } \\
\text { - total, ea } \\
\text { - in\% of the total number of patent applications in the } \\
\text { field of ICT }\end{array}$ & $\begin{array}{c}1,772 \\
0,50\end{array}$ & $\begin{array}{c}1,763 \\
0,44\end{array}$ & $\begin{array}{c}1,898 \\
0,45\end{array}$ & $\begin{array}{c}1,532 \\
0,35\end{array}$ & $\begin{array}{l}\cdots \\
\cdots\end{array}$ \\
\hline Gross value added of the ICT sector, in\% of GDP & $\ldots$ & $\ldots$ & 2.7 & 2.6 & 2.7 \\
\hline $\begin{array}{l}\text { Subscribers of fixed broadband Internet access per } \\
100 \text { people of the population, } e a\end{array}$ & 16.5 & 17.0 & 18.3 & 18.6 & 20.9 \\
\hline $\begin{array}{l}\text { Subscribers of wireless broadband Internet access per } \\
100 \text { people of the population, } e a\end{array}$ & 59.9 & 65.2 & 69.1 & 72.4 & 80.5 \\
\hline $\begin{array}{c}\text { Share of households with Internet access, in \% of the } \\
\text { total number of households } \\
\text { including broadband }\end{array}$ & $\begin{array}{l}67.2 \\
56.5\end{array}$ & $\begin{array}{l}69.9 \\
64.1\end{array}$ & $\begin{array}{l}72.1 \\
66.8\end{array}$ & $\begin{array}{l}74.8 \\
70.7\end{array}$ & $\begin{array}{l}76.3 \\
72.8\end{array}$ \\
\hline $\begin{array}{l}\text { Share of business sector organizations using } \\
\text { broadband Internet, in \% of their total number }\end{array}$ & 80.8 & 81.4 & 78.9 & 80.5 & ... \\
\hline $\begin{array}{l}\text { Share of enterprises in the business sector using } \\
\text { "cloud services", in \% of their total number }\end{array}$ & 11.0 & 13.8 & 18.4 & 20.5 & $\ldots$ \\
\hline $\begin{array}{c}\text { Share of social organizations using broadband } \\
\text { Internet, in\% of their total number: } \\
\text { - healthcare and social services } \\
\text { - higher education } \\
\text { - activities of libraries, archives, club-type } \\
\text { institutions } \\
\text { - activities of museums and protection of historical } \\
\text { sites and buildings }\end{array}$ & $\begin{array}{l}87.8 \\
94.7 \\
55.5 \\
75.4\end{array}$ & $\begin{array}{l}89.1 \\
94.6 \\
62.6 \\
80.6\end{array}$ & $\begin{array}{l}88.4 \\
92.5 \\
64.2 \\
81.3\end{array}$ & $\begin{array}{l}89.9 \\
93.9 \\
67.0 \\
84.1\end{array}$ & $\begin{array}{l}\cdots \\
\cdots\end{array}$ \\
\hline
\end{tabular}


institutional ("soft") infrastructure (Internet, artificial intelligence, etc.), in contrast to the traditional ("hard") infrastructure (roads, bridges, pipelines, airports, etc.), is not so tangible, but its action is often more crucial from the standpoint of modern technological and social processes (economic globalization, cybersecurity, etc.) [13, p. 11].

It is necessary to highlight some prerequisites and trends that determine the need for the rapid development of information infrastructure.

1) Development of digital technologies requires providing the ability to almost instantly or in real time to deliver any amount of information to anywhere in the space in the form required by the consumer, as well as to ensure its storage, processing and protection. It is impossible to implement without a developed ICT infrastructure.

2) Increasing use of the Internet of things will require the transfer of significant amounts of information circulating on a global scale between a huge number of stationary and mobile objects. This necessitates the creation of an integrated communication system covering the entire territory of Russia, as well as those areas of the world that are important for our state from economic, military, political and other points of view.

3) Providing data transmission services to the consumer segment and government bodies, providing mobile access to communication and information services makes it necessary to drastically increase the throughput of networks and communication channels, and to increase their degree of intellectualization. This can only be achieved by using new and promising ICTs such as broadband wireless access and optical technologies.

National project Digital Economy of the Russian
Federation has set a difficult but achievable goal - to triple the volume of the digital economy of Russia - from 3.2 trillion Rubles in 2015 to 9.6 trillion Rubles in 2025 (at prices of 2015). In fact, this corresponds to an increase in the share of the digital economy to $8-10 \%$ of GDP. For this, the following tasks are defined [11]:

- an increase in domestic costs for the development of the digital economy from all sources (by share in gross domestic product) by at least 3 times compared with 2017;

- creation of a stable and secure information and telecommunications infrastructure for high-speed transmission, processing and storage of large amounts of data, accessible to all organizations and households;

- use of predominantly domestic software by state bodies and local authorities.

The data given in table. 2, confirm that the ICT infrastructure in Russia is quite well developed and quite accessible. So, Russian fixed Internet tariffs are lower than similar average tariffs in Western Europe by $44 \%$, and for mobile Internet by $18 \%$. Mobile broadband Internet coverage is over $60 \%$.

Substantial support for the development of ICT infrastructure is provided by state and municipal authorities. Thanks to this support, Wi-Fi deployment projects are being implemented in higher education institutions, libraries, medical institutions, multifunctional centers, and in public transport.

The demand for digital technologies is generally characterized by positive dynamics. The level of digital household development is already quite consistent with

TABLE III. VOLUMES OF ACTION PLAN FINANCING IN THE DIRECTION OF “INFORMATION INFRASTRUCTURE” FOR 2018-2020, MILLION RUBLES

\begin{tabular}{|c|c|c|c|}
\hline Action name & 2018 & 2019 & 2020 \\
\hline $\begin{array}{l}\text { Identification of needs for broadband Internet access services and creation of the General Scheme for the } \\
\text { Development of Communication Networks of the Russian Federation for the period 2018-2024. }\end{array}$ & 120.00 & 0.00 & 0.00 \\
\hline Provide broadband Internet access for the population & 12.366 .00 & $12,991.00$ & $13,413.00$ \\
\hline Provide broadband Internet access to prevention and healthcare facilities & $14,719.96$ & 0.00 & 0.00 \\
\hline Provide broadband Internet access to all public authorities and local governments & 55.00 & 150.00 & 150.00 \\
\hline $\begin{array}{l}\text { Provide coverage of transport infrastructure facilities with communication networks with the possibility of wireless } \\
\text { voice and data transmission }\end{array}$ & 40.00 & 350.00 & 35.00 \\
\hline Introduction of 5G / IMT-2020 mobile radio technology in the Russian Federation & 68.00 & 0.00 & 0.00 \\
\hline $\begin{array}{l}\text { Creation of a global multifunctional information and communication satellite system to cover the territory of the } \\
\text { Russian Federation and the world }\end{array}$ & 0.00 & $49,000.00$ & $250,000.00$ \\
\hline Construction of narrow-band wireless networks of the Internet of things in the Russian Federation & 40.00 & 200.00 & 260.00 \\
\hline $\begin{array}{l}\text { Ensure the availability of data storage and processing services throughout Russia for citizens, business and } \\
\text { government }\end{array}$ & $15,070.14$ & $7,000.00$ & 0.00 \\
\hline $\begin{array}{l}\text { Provide storage and processing of information created by state authorities and local governments in the state single } \\
\text { cloud platform }\end{array}$ & 412.00 & 75.00 & 0.00 \\
\hline $\begin{array}{l}\text { Improve technical regulation of data centers in order to ensure the stability, security and economic efficiency of their } \\
\text { functioning }\end{array}$ & 16.00 & 1.00 & 0.00 \\
\hline Identify the composition of the necessary domestic digital platforms and ensure their implementation & $4,935.00$ & $6,824.00$ & $7,148.00$ \\
\hline Provide the ability to use data in digital platforms & 772,60 & $2,018.31$ & $1,181.22$ \\
\hline $\begin{array}{l}\text { Create domestic digital platforms for the collection, processing and distribution of spatial data and space ERS data, } \\
\text { providing the needs of citizens, business and government }\end{array}$ & $1,942.22$ & $10,572.25$ & $12,609.37$ \\
\hline $\begin{array}{l}\text { Create domestic digital platforms for the collection, processing, storage and distribution of data, earth remote } \\
\text { sensing, providing the needs of citizens, business and government }\end{array}$ & $1,995.00$ & $2,510.00$ & $5,570.00$ \\
\hline Total for the direction & $52,551.92$ & $91,691.56$ & $290,366.59$ \\
\hline
\end{tabular}


TABLE IV. PLAN FOR ACHIEVING INDIVIDUAL VARIABLES AND INDICATORS OF THE FEDERAL PROJECT DIGITAL INFRASTRUCTURE

\begin{tabular}{|c|c|c|c|c|c|c|c|}
\hline Name of variables and indicators & 2018 & 2019 & 2020 & 2021 & 2022 & 2023 & 2024 \\
\hline Share of households with broadband Internet access, $\%$ & 75 & 79 & 84 & 89 & 92 & 95 & 97 \\
\hline $\begin{array}{l}\text { Share of medical organizations of the state and municipal health care system (hospitals and } \\
\text { clinics) connected to the Internet, } \%\end{array}$ & 95 & 100 & 100 & 100 & 100 & 100 & 100 \\
\hline $\begin{array}{l}\text { Share of state (municipal) educational organizations implementing general education and / or } \\
\text { secondary vocational education programs connected to the Internet, } \%\end{array}$ & 39.47 & 59.65 & 79.82 & 100 & 100 & 100 & 100 \\
\hline $\begin{array}{l}\text { Share of state authorities, local governments and state extra-budgetary funds connected to the } \\
\text { Internet, } \%\end{array}$ & 18.82 & 18.82 & 18.82 & 18.82 & 59.4 & 79.7 & 100 \\
\hline $\begin{array}{l}\text { Share of information systems and resources of federal executive bodies and state extra-budgetary } \\
\text { funds transferred to the state unified cloud platform according to the service model, } \%\end{array}$ & - & 15 & 40 & 55 & 55 & 55 & 55 \\
\hline
\end{tabular}

current trends. The number of users of fixed broadband Internet has grown 1.8 times compared with 2011 and amounted to 30.9 million subscribers in 2017 , mobile - 1.7 times, to 117.4 million subscribers. For the period 2010-2017 the proportion of households with Internet access increased 1.6 times - up to $76.3 \%$. $72.6 \%$ of households have broadband Internet. The gap in Internet access for urban and rural residents is narrowing: in 2013 it was 1.5 times (72.8 and $49.5 \%$ of households, respectively), in 2017 - 1.2 times (79.5 and $66,5 \%)$. The spread of the Internet among the population is accompanied by an increase in the intensity of its use: the share of the most active Internet users over the past 8 years has grown 2.3 times, reaching $60.6 \%$ in 2017 [14].

The main objective of the federal project "Information Infrastructure", implemented within the framework of the National Project Digital Economy of the Russian Federation, is to create a global competitive infrastructure for the transfer, processing and storage of data primarily based on domestic developments. To achieve this goal, the federal project provides for the implementation of the following measures:

- creation of a data transmission infrastructure for public authorities and households;

- creation of a data transmission infrastructure for medical and state (municipal) educational organizations implementing programs of general education and / or secondary vocational education;

- development of a new generation of mobile and satellite communications infrastructure;

- creating tools for planning the development of communication networks and stimulating the development of the communications industry;

- development of communication networks at transport infrastructure facilities;

- creation of a global competitive infrastructure for data processing and storage in the Russian Federation;

- introduction of digital technologies and platform solutions in the fields of public administration, business and society.

The volume of financing of measures and the plan for achieving individual indicators of the federal project Digital Infrastructure are presented in table 3 and table 4.

Practical implementation of measures for the implementation of the federal project should be carried out in accordance with the current situation for a particular region, both in terms of the development of digital technologies and in the context of the functioning of the business ecosystem. However, the level of ICT infrastructure development in different regions vary significantly.

CBSR is a region with significant innovative potential, which economy makes a significant contribution to the country's GDP as a whole. An analysis of the current level of the digital technology infrastructure development in the oblasts of the CBSR and the programs implemented in them allows us to identify a steady tendency to expand the use of global information systems in the region (Table 5-7).

Thus, it can be stated that CBSR witnesses stable trends in the widespread use of global information systems, increasing complexity and deepening of the specialization of information technologies. The further development of the digital economy infrastructure in the region is facilitated by the development and implementation of relevant regional state programs.

In particular, the State Program of the Belgorod Region Development of the Information Society in the Belgorod

TABLE V. USE OF PERSONAL COMPUTERS AND THE INTERNET IN HOUSEHOLDS, \% OF THE TOTAL NUMBER OF HOUSEHOLDS IN THE CORRESPONDING CONSTITUENT ENTITY OF THE RUSSIAN FEDERATION

\begin{tabular}{|c|c|c|c|c|c|c|c|c|c|c|c|c|}
\hline \multirow[t]{3}{*}{ Region } & \multicolumn{12}{|c|}{ Share of households possessing } \\
\hline & \multicolumn{4}{|c|}{$P C$} & \multicolumn{4}{|c|}{ Internet access } & \multicolumn{4}{|c|}{ broadband Internet access } \\
\hline & 2014 & 2015 & 2016 & 2017 & 2014 & 2015 & 2016 & 2017 & 2014 & 2015 & 2016 & 2017 \\
\hline Belgorod & 69.0 & 67.2 & 69.2 & 74.4 & 68.9 & 66.4 & 69.4 & 74.8 & 59.6 & 55.4 & 66.2 & 74.2 \\
\hline Lipetsk & 61.9 & 73.7 & 78.2 & 77.6 & 62.4 & 70.9 & 78.0 & 77.8 & 58.9 & 63.1 & 76.5 & 75.6 \\
\hline Voronezh & 61.8 & 60.0 & 68.8 & 70.9 & 61.0 & 61.5 & 71.9 & 73.2 & 54.8 & 56.7 & 70.7 & 73.1 \\
\hline Kursk & 61.5 & 70.8 & 70.5 & 68.9 & 62.1 & 70.4 & 72.0 & 69.3 & 58.3 & 68.0 & 71.8 & 69.3 \\
\hline Tambov & 63.0 & 68.1 & 69.8 & 74.3 & 61.4 & 68.0 & 71.4 & 75.9 & 60.9 & 67.9 & 68.0 & 74.7 \\
\hline
\end{tabular}


TABLE VI. NUMBER OF CONNECTED SUBSCRIBER MOBILE DEVICES PER 1000 PEOPLE OF THE POPULATION, EA

\begin{tabular}{|l|l|l|l|l|l|}
\hline \multicolumn{1}{|c|}{ Region } & $\mathbf{2 0 1 3}$ & $\mathbf{2 0 1 4}$ & $\mathbf{2 0 1 5}$ & $\mathbf{2 0 1 7}$ \\
\hline Belgorod & $1,733.1$ & $1,788.8$ & $1,803.6$ & $1,819.0$ \\
\hline Lipetsk & $1,687.9$ & $1,725.0$ & $1,790.3$ & $1,745.0$ \\
\hline Voronezh & $1,734.6$ & $1,752.8$ & $1,777.9$ & $1,844.2$ & $1,794.8$ \\
\hline Kursk & $1,666.0$ & $1,683.3$ & $1,693.9$ & $1,846.9$ & $1,671.7$ \\
\hline Tambov & $1,665.8$ & $1,694.2$ & $1,776.2$ & $1,675.4$ \\
\hline
\end{tabular}

TABLE VII. ICT USE OF IN THE OBLASTS OF THE CENTRAL BLACK SOIL REGION, IN\% OF THE TOTAL NUMBER OF ORGANIZATIONS SURVEYED IN THE CORRESPONDING SUBJECT OF THE RUSSIAN FEDERATION

\begin{tabular}{|c|c|c|c|c|c|c|c|c|c|c|c|c|}
\hline \multirow[t]{2}{*}{ Region } & \multicolumn{3}{|c|}{ PCs } & \multicolumn{3}{|c|}{ servers } & \multicolumn{3}{|c|}{ local computer networks } & \multicolumn{3}{|c|}{ global information networks } \\
\hline & 2015 & 2016 & 2017 & 2015 & 2016 & 2017 & 2015 & 2016 & 2017 & 2015 & 2016 & 2017 \\
\hline Belgorod $\mathrm{r}$ & 97.5 & 97.9 & 96.7 & 47.9 & 52.6 & 53.7 & 68.0 & 67.5 & 66.9 & 93.6 & 95.5 & 95.0 \\
\hline Lipetsk & 95.6 & 95.1 & 99.8 & 50.3 & 52.2 & 55.3 & 68.3 & 59.7 & 63.8 & 92.2 & 92.5 & 97.8 \\
\hline Voronezh & 94.6 & 93.2 & 91.9 & 36.5 & 39.2 & 39.6 & 59.1 & 58.8 & 55.5 & 86.5 & 85.1 & 85.8 \\
\hline Kursk & 96.7 & 97.0 & 95.2 & 47.8 & 49.9 & 47.8 & 63.4 & 63.2 & 60.6 & 94.1 & 94.8 & 93.5 \\
\hline Tambov & 90.6 & 93.6 & 97.2 & 35.6 & 42.6 & 42.4 & 69.3 & 71.1 & 72.2 & 87.7 & 91.6 & 95.6 \\
\hline
\end{tabular}

Region provides for [15]:

- an increase in the share of households with broadband Internet access up to $97 \%$ by 2025 ;

- an increase in the share of citizens using the mechanism for obtaining state and municipal services in electronic form, up to $75 \%$ by 2020 ;

- ensuring the maintenance of the share of citizens satisfied with the quality of public services at the level of $90 \%$ by 2025 .

The Voronezh region is implementing a regional priority project "Digital School", which will allow in 2020 to organize for 773 general educational and professional educational organizations a high-speed secure data transmission network that includes modern information services (electronic library, video conferencing, a single archive of electronic documents, etc.) $[16]$

To successfully implement these programs, the regions conclude agreements and contracts with leading telecommunication companies in Russia. In particular, the Voronezh region, established cooperation with ER-Telecom Holding companies [17], an agreement was signed between the Belgorod region and the ANO Tsifrovaya ekonomika [18], the Kursk region closely cooperates with MegaFon [19], MTS and the administration of the Lipetsk region announced a strategic partnership in the framework of projects aimed at digitalizing the economy [20].

\section{CONCLUSIONS}

The CBSR oblasts occupy high positions in the rating of the Digital Russia Index (Table 8), which is calculated by the Moscow School of Management SKOLKOVO for all 85 constituent entities of the Russian Federation [21].
TABLE VIII. DIGITALIZATION INDEX OF THE CBSR OBLASTS

\begin{tabular}{|l|l|l|}
\hline \multicolumn{1}{|c|}{ Region } & \multicolumn{1}{c|}{ Rating position } & \multicolumn{1}{c|}{ Point } \\
\hline Belgorod region & 11 & 73.09 \\
\hline Lipetsk region & 14 & 72.37 \\
\hline Voronezh region & 20 & 70.93 \\
\hline Kursk region & 24 & 68.7 \\
\hline Tambov region & 48 & 55.86 \\
\hline
\end{tabular}

Considering that the arithmetic mean value of this index for Russia as a whole as of June 30, 2018 is 55.94 points (out of the maximum possible 100 points), and 59.82 points for the regions of the Central Federal District, it can be concluded that the activities carried out comply to state strategic approaches and global trends in the development of digital technologies and projects. At the same time, the general trends in the development of digital technologies are very dynamic and can change, which will entail a partial review and adjustment of the measures taken.

\section{References}

[1] S.D. Bodunov, Noonomics: monograph. M.: Kul'turnaya revolyutsiya, 432 p., 2018 (in Russian).

[2] S.A. Tolkachev, N.M. Abdikeev, and M.V. Melenchuk, Competitiveness of socio-economic systems in the context of the digital transformation of the Russian economy: monograph (joint). M.: Prometei, 354 p., 2019 (in Russian).

[3] V.E. Korolkov and T.A. Erofeyeva, Digital transformation of the economy in geo-economic instability: Monograph. M.: Prometei, 160 p., 2019 (in Russian)

[4] A. Weigend, BIG DATA. Data for the people. Tr. from English by S. Bogdanov. Moscow: Eksmo, 384 p., 2019.

[5] M. Krantz, Internet of things: a new technological revolution. Tr. from English by Z. Mamediarov. Moscow: Eksmo, 336 p., 2018 (in Russian). 
Report at the $20^{\text {th }}$ April International research conference on the problems of economic and social development. Ed. by L.M. Gokhberg, Moscow, 9-12 April 2019, M.: Publishing House of the Higher School of Economics, 82 p., 2019 (in Russian).

[15] Official site of the Governor and Government of the Belgorod Region [Electronic resource]. Available at: https://belregion.ru/_(in Russian).

[16] "Digital economy", Regional government discussed the preparation of the regional element of the national project [Electronic resource]. Available at: https://www.govvrn.ru/novost/-/ /id/3126943 (in Russian).

[17] Voronezh Governor discussed important investment projects with businessmen [Electronic resource]. Available at: https://www.vrn.kp.ru/daily/27068/4137895/ (in Russian).

[18] The Belgorod region and Tsifrovaya ekonomika will jointly launch technological projects [Electronic resource]. Available at: https://dataeconomy.ru/13092019 (in Russian).

[19] MegaFon i Kurskaya and Kursk oblast have agreed on joint development of digital economy [Electronic resource]. Available at: https://kursk.bezformata.com/listnews/megafon-i-kurskaya-oblastdogovorilis/76631412/(in Russian).

[20] MTS and the Administration of the Lipetsk oblast announced partnership in the sphere of the digital economy development in the region [Electronic resource]. Available at: https://cnews.ru/news/line/2019-09-10_mts_i_administratsiya_ lipetskoj_(in Russian).

[21] Index Digital Russia [Electronic resource]. Available at: https://finance.skolkovo.ru/downloads/documents/FinChair/Research_ Reports/SKOLKOVO_Digital_Russia_Report_Full_2019-04_ru. pdf_(in Russian).

[14] G.I. Abdrakhmanova, K.O. Vishnevsky, L.M. Gokhberg and et al., What is a digital economy? Trends, competencies, measurement, 